\title{
The Influence of Snow Cover Changes on Red Deer (Cervus elaphus L.) Migrations in the Western Part of Gorski Kotar Region in Croatia
}

\author{
Josip Malnar ${ }^{1}$, Marijan Grubešić ${ }^{2}$, Damir Ugarković ${ }^{3 \Xi}$
}

${ }^{1}$ Croatian Forests Ltd. Zagreb, Forest Administration Delnice, Forest Office Gerovo, Pilanska 13, HR-51304 Gerovo, Croatia

${ }^{2}$ University of Zagreb, Faculty of Forestry, Department of Forest Protection and Wildlife Management, Svetošimunska 25, HR-10000 Zagreb, Croatia

${ }^{3}$ University of Zagreb, Faculty of Forestry, Department of Forest Ecology and Silviculture, Svetošimunska 25, HR-10000 Zagreb, Croatia

$\checkmark$ Corresponding author: e-mail: damir.ugarkovic@gs.htnet.hr

Citation:

MALNAR J, GRUBEŠIĆ M, UGARKOVIĆ D 2015 The Influence of Snow Cover Changes on Red Deer (Cervus elaphus L.) Migrations in the Western Part of Gorski Kotar Region in Croatia. South-east Eur for 6 (1): 65-75. DOI: http://dx.doi.org/10.15177/seefor.15-07

\section{Abstract}

Background and Purpose: Animal migrations are a direct result of reproduction, behaviour characteristics, predators, population density, disturbance, loss of habitat, climatic, vegetational and nutritional factors. The availability and accessibility of natural food in winter months is dependent on snow cover. The main objective of this study was to determine the migrational activities of red deer and to examine the dependency between migrations and climatic factors.

Materials and Methods: The study was carried out in the northwest Dinarid mountains, i.e. in the western part of Gorski Kotar region, which represents a large integral forest complex, distinctive due to its significant vertical drops, diverse relief characteristics and habitat conditions. Data on red deer migrations was collected over a 12 year period from hunting records, gamekeeper logs and records from game counting and monitoring.

Results and Conclusions: The results of the macroclimatic analysis show a statistically significant difference $(p<0.05)$ between the monitored weather stations in the study area. The Klana site stood out as the most appropriate red deer winter habitat, based on climatic conditions. Climatic conditions play a key role in seasonal red deer migrations or non-migrations. The Crni Lug site was assessed to be the least favourable due to macroclimatic conditions (snow depth).

Keywords: snow cover, red deer (Cervus elaphus L.), migration, Gorski Kotar 


\section{INTRODUCTION}

Red deer (Cervus elaphus L.) is a common game animal in both the coastal and mountainous parts of the northwestern Dinarid mountain range (Gorski Kotar region) of Croatia, including areas near the Slovenian border. In the latter half of the $19^{\text {th }}$ century, red deer almost completely vanished from this area, but was quickly reintroduced in Slovenia [1]. From here, it soon migrated back into the Gorski Kotar region. Therefore, it can be considered to be an indigenous species. The number of individuals and spatial distribution following reintroduction started to grow, slowly at first and much more rapidly in the second half of the $20^{\text {th }}$ century, due to multiple factors: regulation of hunting legislation that protected large herbivore ungulates, systematic destruction of large predators, overgrown abandoned agricultural areas, intensive forest exploitation and intensive nutrition with game feeders [1].

As a result, deer inhabits large expanses of the forested area in the Gorski Kotar region in Croatia. Hunting management programmes have estimated the total population at 970 individuals in the western part of Gorski Kotar region [1].

In order to consider deer game management within modern ecological conditions, it is essential to stress that changes in the ecology affect game behaviour, as animals changing their rhythm and behavioural patterns accordingly. Knowing how these changes impact animal populations, it is possible to take adequate breeding measures on hunting grounds, remove negative consequences and drawbacks observed to cause disturbances in herds, and determine the tolerance limits between game animals and habitat.

It is important to know that deer favour certain pastures, that they enjoy a variety of herbal food, including fruits and seeds, and occupy different sites for feeding, rest and sleeping. They seek out specific shelters from predators, and open spaces for playing and mating. Access to water is particularly important, especially in areas where does raises their young. It is a well known fact that deer often visit feeders during the winter months, and thus an appropriate spatial distribution of such structures is essential for their survival.

In order to meet these needs, deer have seasonal migrations, i.e. they have both winter and summer habitats and separate habitats for the mating season. It is also very important to know the spatial distribution of herds. It is well known that during their lifetime, deer inhabit a much smaller range than other migrating animals. Migration is movement from one area into another, though it is also important to note that it represents a periodical movement that includes returning to the starting area [2]. Partial migrations are those in which only a portion of the population migrates, while the remainder remains in the same period throughout the year. This is a typical occurrence in environments with high seasonal variation. This occurrence has been recorded for all indigenous deer species in Scandinavia, and also for small ruminants, such as roe deer Capreolus capreolus [3], large ruminants such as moose Alces alces [4], and also for red deer [5]. Seasonal migrations are a well-known occurrence among large herbivores, which is caused by the availability of food, and risks from predators [6]. Red deer in the temporal belt regularly migrate from higher elevations in summer to lower elevations in winter [3, $5,7]$ in order to reach areas with better snow conditions [8].

The depth of the snow cover at high elevations spurs animals to migrate to lower elevations $[3,7,9]$. According to Mysterud et al. [10], the share of migrating deer in the total population is from 38 to $100 \%$, and migrations are typical in areas with diverse relief and in high elevation areas.

Migrations in the Gorski Kotar region are the result of reproduction, behaviour characteristics, predators, population density, disturbance, loss of habitat, climatic, vegetational, and nutritional factors. Distances covered during migration may be shorter or longer, depending on the severity of climatic 
conditions and food availability. Such seasonal migrations are related to climatic conditions, resulting in a range of habitats used by animals depending on the season.

The spatial behaviour of mammals is influenced by several factors: metabolic needs, body weight, nutritional habits and the mating season [11-13]. Habitat size is also related to a combination of other factors, such as age [14, 15], population density [16], predators and human interference [17]. The winter habitat is typically a more concentrated area in which animals are forced to move due to a lack of food [18].

Due to weather conditions, the environment can change through natural variations, either due to the availability of food due the depth of the snow cover, or due to the intensity of grazing and the season [19]. In dealing with the environment, deer can migrate towards summer or winter areas, and can cover great distances in doing so [20-22]. Vertical migrations from higher to lower elevations are a typical model of migration as a strategy in trying to meet energy needs [23]. Such migrations are caused by the depth of snow cover at high altitudes during winter and ultimately due to the change in seasons and the varying quality and quantity of available food for animals [24].

When the Bavarian Alps region becomes accessible following the snow melt, deer are known to temporarily and briefly migrate outside their usual small wintering areas. In the Alps, winter and rutting ranges are relatively small, averaging 113 ha and 134 ha, respectively, whereas the mean size of home ranges used from spring to autumn amounts is 386 ha [25].

Habitat structure and food quality and distribution have the greatest influence on habitat size. In this context, the metabolic ratio and food consumption are reduced in ruminants in moderate climates of the northern hemisphere during the winter period, as a period traditionally associated with weight loss [26]. In these areas, ruminants preserve energy during winter by reducing activities and movement within the limited habitat [25, 27-29].
When determining food availability, snow cover is a relevant factor that significantly reduces food availability and accessibility during the winter period. Therefore, during winter, snow cover and temperature are considered to be extremely important factors for determining spatial behaviour of many mountain ruminant species.

The strategy for compensating for difficult winter conditions could include migrations to lower valleys with less snow during winter and, most importantly, to the rich pastures at higher elevations during summer. Migration can have a strong influence on the spatial behaviour of each individual adopting this strategy: many populations of large ruminants migrate seasonally between separate life areas [30]. Alternative strategies such as migrations or non-migrations can occur within the same population due to environmental fluctuations and migration cost differences for specific individuals [4]. Usually, migrating ruminants in moderate climates, such as red deer, choose higher summer habitats and lower winter habitats [5].

It is commonly agreed that migration towards lower areas in the fall and early winter represents a strategy that involves finding winter habitats with smaller snow depths [8], due to the fact that deeper snow cover reduces food accessibility, increases energy consumption due to movement [31] and makes deer more vulnerable to predators [32].

In the Alps, during harsh winter conditions with deep snow cover, red deer select areas of alpine pastures under the tree line, where the snow is less deep, the insolation is greater and feed availability is good due to the fragmented distribution of the snow. Energy expenditures for thermoregulation are minimised by selecting areas with a southern or southwestern exposition, protected from strong winds. In years with less snow, red deer that are not fed prefer the security of forest habitats at lower elevations, and graze on the valley meadows.

Red deer receiving supplementary feeding have more constant ranges, and save energy 
by combining the alpine pastures with feeding areas [33].

Fast spring migration in Norway is significantly different from other reports of slow deer spring migrations due to the gradual greenification on the elevation gradient $[5,18]$.

In the Republic of Croatia, ecological research on deer game populations has been conducted in the Podunavlje area [34]. Part of the study was focused on deer migrations and spatial separation of the sexes, except in the mating season when male and female individuals were together. Outside the mating season, herds of female units with calves occupy one part of the hunting ground, while males occupy another.

The exact snow cover depths at which animals will alter their life habits, i.e. migrate into more acceptable climate conditions regardless of nutrition quality, is known for all wild ungulate species. The critical snow cover depth that causes migration among red deer is from $50-60 \mathrm{~cm}$ [35].

The main objectives of this study were to determine the changes in snow cover depths that are significant for red deer migrations and to examine dependencies between migrations and climatic factors (number of days with snow depths $\geq 50 \mathrm{~cm}$ and maximum daily snow depths) in the context of their changes in the western part of Gorski Kotar region.

\section{MATERIALS AND METHODS}

\section{Study Area}

The study was conducted in the western part of Gorski Kotar region. According to the Köppen classification, the study area is included in the Cfsbx climate type. This is a moderately warm rain climate, without dry periods. Based on the data from the Parg weather station, the average annual air temperature for the study area is $7^{\circ} \mathrm{C}$, and the average precipitation is approximately $2000 \mathrm{~mm}$ [36]. Relief of the study area is extremely irregular and meuble.

Gorski Kotar region in Croatia represents a large integral forest complex, distinctive for its significant vertical drops, and diversity of relief characteristics and habitat conditions (Figure 1).

The study area includes a smaller section of the coastal region (Klana, Grobnik) which

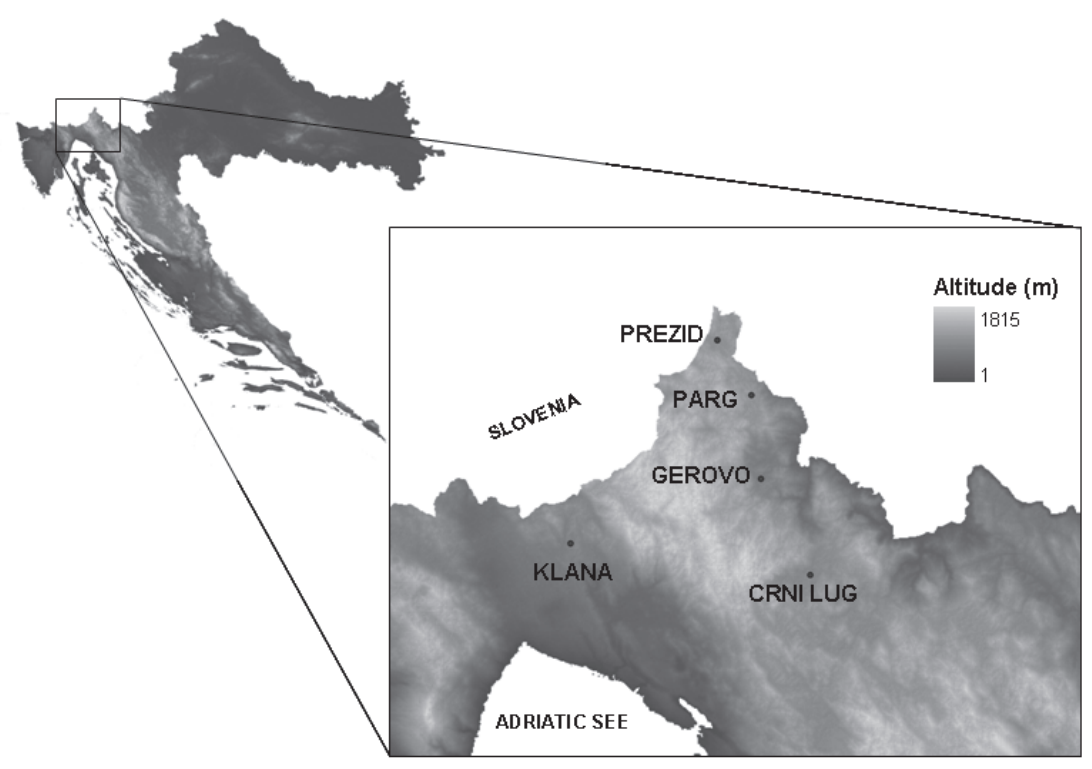

FIGURE 1. Study area 
represents the winter habitat, and an inland region (Parg, Gerovo, Prezid, Crni Lug) from which the deer migrate.

\section{Snow Analysis}

In the study area, data on the number of days with snow depths $\geq 50 \mathrm{~cm}$ and maximum daily snow depths $(\geq 50 \mathrm{~cm})$ were analysed for the winter period from 1950 to 2011 from the weather stations Parg, Gerovo, Prezid, Crni Lug and Klana. A reduction or increase of climate elements was analysed using a linear trend, and the significance of the linear trend was tested with the Student's t-test. All climate data was processed using the KlimaSoft 2.0 software (Monachus informatika, Croatia). Statistical data analysis (regression analysis, Student's t-test) was conducted using Statistica 7.1 software [37] with a $5 \%$ significance level considered statistically significant.

\section{Game Observations}

Hunting authorities are obliged by law to perform regular counts of all game species that permanently or temporarily inhabit hunting grounds [38, 39]. There are numerous known and acknowledged methods for determining the number of individuals. The most commonly used method for counting big game is observation and monitoring throughout the year, at several known locations. Data were collected on red deer migrations from the hunting records, gamekeeper logs and records from game counts and monitoring activities in the study area. Counts and monitoring the red deer population was carried out in an area of 75206 ha in the winter period, i.e. from October to December, in the years 2000 to 2011. Outgoing migrations were analysed to determine whether they were caused by snow cover, regardless of the number of migratory individuals. In total, 132 count records, hunting records and gamekeeper logs were analysed. The red deer population in the study area was assessed at 970 individuals [1].

Data from weather stations was analysed to determine the existence or non-existence of a critical snow depth $(\geq 50 \mathrm{~cm})$ for this study area during the winter months. Based on game counts, red deer monitoring data from gamekeeper logs and hunting records were analysed. If migration individuals were observed and the snow depth was $>50 \mathrm{~cm}$, this was assigned a score of 1 , while if there was no migration and the snow depth was $<50$ $\mathrm{cm}$, this was assigned a score of 0 . Regression analysis was used to determine whether there was a correlation between red deer migrations and snow cover depth.

\section{RESULTS AND DISCUSSION}

Based on many years of experience in monitoring red deer activities in the study area, particularly activities related to the start of the seasonal migration, it can be assumed that climate conditions, such as snow cover depth and duration, represent the main factor influencing migrations. Therefore, the focus of this study was directed at these climate conditions.

When considering the number of days with snow depth $\geq 50 \mathrm{~cm}$, there was a significant difference between the Klana site, which represents the red deer winter habitat, and the inland sections of the western part of Gorski Kotar region (sites Gerovo, Crni Lug, Prezid, Parg) from where red deer game usually migrates.

The average number of days with snow depth $\geq 50 \mathrm{~cm}$ at the Klana site was 0.33 days, while at Prezid, Parg, Gerovo and Crni Lug area, this number varied from 10.18 to 17.25 days (Table 1). The Klana site had the fewest number of days with snow cover, which explains deer migrations from the inner areas of the western part of Gorski Kotar region, i.e. from the sites Gerovo, Crni Lug, Prezid and Parg.

The results in Table 2 clearly indicate that the area near the Klana weather station is the winter habitat with the smallest maximum daily snow depths. Maximum daily snow depths at the Klana area was $18.93 \mathrm{~cm}$, as opposed to the 
TABLE 1. Comparison of the mean number of days per winter season with snow cover $\geq 50 \mathrm{~cm}$ (period from 1950 to 2011)

\begin{tabular}{cc}
\hline Weather station & Mean \pm Std. Dev. \\
\hline Klana & $0.33 \pm 1.11^{\mathrm{a}}$ \\
Gerovo & $12.80 \pm 17.91^{\mathrm{bc}}$ \\
Crni Lug & $17.25 \pm 18.18^{\mathrm{b}}$ \\
Prezid & $10.18 \pm 14.29^{\mathrm{c}}$ \\
Parg & $10.76 \pm 13.61^{\mathrm{c}}$ \\
\hline
\end{tabular}

Note: Values within a column marked with a different letter differ significantly $(p<0.05)$; Std. Dev. - standard deviation

maximum daily snow depths in the areas from which the red deer migrated, which ranged from $38.47 \mathrm{~cm}$ to $79.76 \mathrm{~cm}$. It can be assumed that this was the reason for red deer migrations from the Prezid, Parg, Gerovo and Crni Lug areas into the winter habitats at Klana.

Based on the results of the study and analysis of macroclimate conditions (number of days with snow depths $\geq 50 \mathrm{~cm}$ and maximum daily snow depths), it is clear that there is a certain regularity, seen in the statistically significant difference between observed weather stations in the study area. The Klana site stands out from all other weather stations concerning the variables examined. As Table 2 shows, more favourable macroclimate conditions play the
TABLE 2. Comparison of mean values of the maximum daily amount of snow cover $(\mathrm{cm})$ for the period 1950 to 2011

\begin{tabular}{lc}
\hline Weather station & Mean \pm Std. Dev. \\
\hline Klana & $18.93 \pm 18.03^{\mathrm{a}}$ \\
Gerovo & $71.08 \pm 40.85^{\mathrm{b}}$ \\
Crni Lug & $79.76 \pm 37.91^{\mathrm{b}}$ \\
Prezid & $70.38 \pm 46.75^{\mathrm{b}}$ \\
Parg & $38.47 \pm 13.09^{\mathrm{c}}$ \\
\hline
\end{tabular}

Note: Values within a column marked with a different letter differ significantly $(p<0.05)$; Std. Dev. - standard deviation

main role in seasonal game migrations, in this case red deer migrations. Of all the weather stations, Crni Lug was shown to have the least favourable macroclimate conditions (snow cover depths).

Trends related to the number of days with snow and maximum daily snow depths in the northwest Dinarid region are negative. A significant reduction in the number of days with snow $\geq 50 \mathrm{~cm}$ was seen at the Crni Lug and Prezid sites, which are areas from which red deer usually migrate during winter months. A significant reduction in maximum daily snow depths was present at the sites Gerovo, Crni Lug and Prezid, which are also areas from which red deer usually migrate (Table 3).

TABLE 3. Linear trends number of days per winter season with snow $\geq 50 \mathrm{~cm}$ and maximum daily snow depth $(\mathrm{cm})$ for the period 1950 to 2011

\begin{tabular}{llllll}
\hline Weather station & Linear trend & Beta & B & t & p-level \\
\hline \multicolumn{7}{c}{ Number of days with snow $\geq 50 \mathrm{~cm}$} \\
Klana & $\mathrm{Y}=-0.0028 \mathrm{x}+0.4181$ & -0.0435 & -0.0028 & -0.3317 & 0.7412 \\
Gerovo & $\mathrm{Y}=-0.1026 \mathrm{x}+15.931$ & -0.1000 & -0.1026 & -0.7657 & 0.4469 \\
Crni Lug & $\mathrm{Y}=-0.2725 \mathrm{x}+25.61$ & -0.2616 & -0.2725 & -2.0643 & $0.0434^{*}$ \\
Prezid & $\mathrm{Y}=-0.2256 \mathrm{x}+17.077$ & -0.2757 & -0.2256 & -2.1844 & $0.0329^{*}$ \\
Parg & $\mathrm{Y}=0.0087 \mathrm{x}+10.502$ & 0.0111 & 0.0087 & 0.0847 & 0.9327 \\
\hline \multicolumn{6}{c}{ Maximum daily snow depth $(\mathrm{cm})$} \\
Klana & $\mathrm{Y}=-0.0792 \mathrm{x}+21.349$ & -0.0767 & -0.0792 & -0.5858 & 0.5602 \\
Gerovo & $\mathrm{Y}=-0.6156 \mathrm{x}+89.86$ & -0.2632 & -0.616 & -2.0777 & $0.0421^{*}$ \\
Crni Lug & $\mathrm{Y}=-0.7452 \mathrm{x}+102.49$ & -0.3433 & -0.745 & -2.7837 & $0.0072^{*}$ \\
Prezid & $\mathrm{Y}=-0.8916 \mathrm{x}+97.576$ & -0.3330 & -0.892 & -2.6899 & $0.0093^{*}$ \\
Parg & $\mathrm{Y}=-0.087 \mathrm{x}+41.08$ & -0.1142 & -0.0857 & -0.8761 & 0.3845 \\
\hline
\end{tabular}

* significant at $p<0.05$ 
In recent years, the number of days with snow and the maximum daily snow depth values have declined, which will certainly reflect on the intensity of red deer migrations in the northwest Dinarid region. According to Malnar [1], in the period 2005 to 2009 at the sites Parg, Prezid, Crni Lug and Gerovo, the number of days with snow $\geq 10 \mathrm{~cm}$ was reduced by $20 \%$, number of days with snow $\geq 30 \mathrm{~cm}$ was reduced by $38 \%$ and number of days with snow $\geq 50 \mathrm{~cm}$ was reduced by as much as $54 \%$ in comparison to reference period from 1961 to 1990.

Red deer migrations in the northwest Dinarid region have been much less frequent in recent years. The significant climate changes that have appeared, or will appear in the future, will have serious biological and ecological consequences on forest ecosystems and wildlife. Air temperature is a decisive factor for climate character. According to Ugarković and Tikvić [40], average annual air temperatures in the Gorski Kotar region had shown a statistically significant increase of $0.5^{\circ} \mathrm{C}$ to $1.0^{\circ} \mathrm{C}$, for the period 1991 to 2007, in comparison to the reference period (1961-1990). In line with the increased average annual air temperatures and significantly positive trend in absolute maximum air temperatures, the number of warm days $\left(\geq 25^{\circ} \mathrm{C}\right)$ per winter season has increased by 10-14 days and the number of hot days $\left(\geq 30^{\circ} \mathrm{C}\right.$ ) by $1-3$ days during the years 1991 to 2007, while snow precipitation has been declining.

Due to the increase in air temperature, snow cover depths in the northern hemisphere have been reduced by $10 \%$ in the last 20 years [41]. The average number of days per winter season with critical snow depths $(\geq 50 \mathrm{~cm})$ was only 2 days for the Gerovo site, and not a single day for the Klana site (Table 4) for the period from 2000 to 2011 . The inland sections of the Gorski Kotar region had shown only 5 years with critical snow depths $(\geq 50 \mathrm{~cm})$. These data corroborate the reductions in red deer migration in the Gorski Kotar region obtained by observing and telemetric monitoring.

According to Hafner [35], the critical snow depths that caused migrational activities of
TABLE 4. Number of days per winter season with snow $\geq 50 \mathrm{~cm}$ at the weather stations Gerovo and Klana

\begin{tabular}{ccc}
\hline \multirow{2}{*}{ Years } & \multicolumn{2}{c}{ Weather stations } \\
\cline { 2 - 3 } 2000 & Gerovo & Klana \\
2001 & 0 & 0 \\
2002 & 1 & 0 \\
2003 & 0 & 0 \\
2004 & 7 & 0 \\
2005 & 22 & 0 \\
2006 & 11 & 0 \\
2007 & 0 & 0 \\
2008 & 0 & 0 \\
2009 & 0 & 0 \\
2010 & 0 & 0 \\
2011 & 47 & 0 \\
\hline Average & 0 & 0 \\
\hline
\end{tabular}

the red deer were $50-60 \mathrm{~cm}$. In the observed migration period, such critical depths were recorded in 5 years at the Gerovo site. The average maximum daily snow depths were $50 \mathrm{~cm}$ at the Gerovo site and $12.7 \mathrm{~cm}$ at the Klana site. Maximum daily snow depths in the northwest Dinarid region were the cause of lesser migrational activities of deer game (Table 5).

TABLE 5. Maximum daily snow depth (cm)

\begin{tabular}{ccc}
\hline \multirow{2}{*}{ Years } & \multicolumn{2}{c}{ Weather stations } \\
\cline { 2 - 3 } & Gerovo & Klana \\
\hline 2000 & 17 & 1 \\
2001 & 56 & 28 \\
2002 & 36 & 0 \\
2003 & 57 & 18 \\
2004 & 100 & 11 \\
2005 & 61 & 34 \\
2006 & 45 & 8 \\
2007 & 37 & 3 \\
2008 & 34 & 6 \\
2009 & 41 & 8 \\
2010 & 93 & 31 \\
2011 & 23 & 4 \\
\hline Average & 50 & 12.7 \\
\hline
\end{tabular}


Reduced food availability and snow cover can reduce winter mobility in red deer $[25,33]$ and roe deer (Capreolus capreolus L.) [42, 43].

Multiple regression analysis showed that the number of snow days and the maximum daily snow depths $(\geq 50 \mathrm{~cm}$ ) have a significant influence on red deer migrations. Snow as the climate factor explained $29.28 \%$ of red deer migrations in the study area (Table 6).

In the Italian Alps region, the time of migratory deer migrations is connected to snow cover, since this region is under the inverse influence (although weak) of snow precipitation intensity, and is more prominently correlated with winter snow precipitation, where only $2 \mathrm{~cm}$ of snow was enough to trigger the migration of migratory deer from their summer habitats into their winter habitats. On the other hand, stationary red deer are under a very mild influence of snow conditions, likely due to the lower elevation of their habitats as compared to migratory deer, which significantly reduces the snow influence [44].

Regional differences in topography, habitat accessibility or climate not only influence the share of migratory individuals and specific details related to the seasonal movement of deer game; they are likely the actual cause for the migrations. Such spatial behaviour confirms that red deer avoid snow, as estimated in other studies in mountainous environments $[25,33$, 45 ], and that the presence of snow cover is the main factor in determining the fall migration of this species.

According to some researchers, seasonal migrants such as red deer have medium sized habitats [5]. Unlike red deer, roe deer is a stationary animal with a small habitat and few migratory individuals [46]. Luccarini et al. [44] determined two types of behaviour of the red deer in Italian Alps - migratory and stationary. In that study, migratory and stationary individuals were equally distributed between sexes.

Stationary deer use areas of comparable size during spring, summer and fall, while their winter areas were considerably smaller. Migratory deer used large sized areas in the fall and the spring, considerably larger than their summer habitats, and substantially larger than those used in winter. Therefore, regardless of the selected strategy, winter habitats were significantly smaller.

These results support other findings of a strong influence of climate conditions on the spatial behaviour of ruminants, particularly of snow cover as the decisive factor in the winter period. Furthermore, the size of the winter habitat is dependent on the severity of winter: the deeper the snow, the smaller the habitat animals use [25].

According to Luccarini et al. [44], migratory and stationary animals in the Alps region show periodic vertical movements throughout the year, reaching the highest altitudes during summer and lowest during winter months. This aspect is emphasised in the case of migratory deer, which reached distant summer habitats, located at the highest altitudes, every year, while stationary deer simply increased their use of higher areas, but did not reach those altitudes used by migratory deer.

The deer monitored in the northwest Dinarid region showed little migratory activity due to warm winters, i.e. low number of days with critical snow depths (Table 4) and small maximum daily snow depths (Table 5 ).

TABLE 6. Multiple regression analysis of the dependencies between the number of snow days and maximum daily snow depths $(\geq 50 \mathrm{~cm})$ and red deer migrations

\begin{tabular}{cccccccc}
\hline & Beta & $\begin{array}{c}\text { Std. Err. } \\
\text { of Beta }\end{array}$ & B & $\begin{array}{c}\text { Std. Err. } \\
\text { of B }\end{array}$ & t (10) & p-level & $\begin{array}{c}\text { Adjusted } \\
\mathbf{R}^{2}\end{array}$ \\
\hline Intercept & & & 0.3750 & 0.1530 & 2.4494 & 0.0342 & 0.2928 \\
Climatic factor (snow) & 0.5976 & 0.2535 & 0.6250 & 0.2651 & 2.3570 & 0.0401 & \\
\hline
\end{tabular}




\section{CONCLUSIONS}

The macroclimatic conditions (number of days with snow depth $\geq 50 \mathrm{~cm}$ and maximum daily snow depths) showed a certain regularity, i.e. a statistically significant difference between the observed weather stations in the study area. The Klana weather station was shown to be the most favourable deer game winter habitat based on all the study variables. As for the other weather stations, Crni Lug was found to be the habitat with the least favourable macroclimatic conditions (snow depth).

Due to growing changes in climate and climatic conditions in the northwest Dinarid region, a new trend has emerged, with a decline in the number of snow days and maximum daily snow depths $\geq 50 \mathrm{~cm}$. For that reason, years without snow precipitation or without critical snow depths that would otherwise influence migrations, are becoming more frequent. Therefore, red deer have reduced the intensity of their migrations in the study area. However, in years with critical snow depths $(\geq 50 \mathrm{~cm})$, migrations are still present. According to the results (Table 6 ), the monitored climatic factors (number of snow days and maximum daily snow depths $\geq 50 \mathrm{~cm}$ ) have a significant influence on red deer migrations. These two factors alone explain $29 \%$ of red deer migrations in the study area. Naturally, migrations are also influenced by other factors such as food availability, which in turn is related to the amounts of snow, winter feeding, human activities and game disturbances, presence of predators, etc.

\section{REFERENCES}

1. MALNAR J 2011 Migration of Red deer (Cervus elaphus L.) in Western part of Gorski kotar affected by biotope factors (in Croatian with English summary). PhD thesis, University of Zagreb, Faculty of Forestry, Zagreb, Croatia, $133 \mathrm{p}$

2. DEGMEČĆC D 2011 Selection of red and roe deer (in Croatian). Hrvatski lovački savez, Zagreb, Croatia, $112 p$

3. MYSTERUD A 1999 Seasonal migration pattern and home range of roe deer (Capreolus capreolus) in an altitudinal gradient in southern Norway. J Zool 247 (4): 479-486. DOI: http://dx.doi. org/10.1111/j.1469-7998.1999.tb01011.x

4. BALL JP, NORDENGREN C, WALLKIN K 2001 Partial migration by large ungulates: characteristics of seasonal moose Alces alces range in northern Sweden. Wildlife Biol 7 (1): 39-47

5. ALBON SD, LANGVATN R 1992 Plant phenology and the benefits of migration in a temperate ungulate. Oikos 65 (3): 502-513. DOI: http:// dx.doi.org/10.2307/3545568

6. FRYXELL JM, SINCLAIR ARE 1988 Causes and consequences of migration by large herbivores. Trends Ecol Evol 3 (9): 237-241. DOI: http://dx.doi. org/10.1016/0169-5347(88)90166-8

7. BRAZDA AR 1953 Elk migration patterns and some of the factors affecting movements in the Gallatin River drainage, Montana. J Wildlife Manage 17 (1): 9-23. DOI: http://dx.doi.org/10.2307/3796798

8. NELSON ME 1995 Winter range arrival and departure of white-tailed deer in northeastern Minnesota. Can J Zoolog 73 (6): 1069-1076. DOI: http://dx.doi.org/10.1139/z95-127

9. BOYCE SM 1991 Migratory behaviour and management of elk (Cervus elaphus). Appl Anim Behav Sci 29 (1-4): 239-250. DOI: http://dx.doi. org/10.1016/0168-1591(91)90251-R

10. MYSTERUD A, LOE LE, ZIMMERMANN B, BISCHOF $R$, VEIBERG $V$, MEISINGSET E 2011 Partial migration in expanding red deer populations at northern latitudes - a role for density dependence? Oikos 120 (12): 1817-1825. DOI: http://dx.doi. org/10.1111/j.1600-0706.2011.19439.x

11. LINDSTEDT SL, MILLER BJ, BUSKIRK SW 1986 Home-range, time, and body size in mammals. Ecology 67 (2): 413-418. DOI: http://dx.doi. org/10.2307/1938584

12. CLUTTON-BROCK TH 1989 Mammalian mating system. P Roy Soc B-Biol Sci 236 (1285): 339-372. DOI: http://dx.doi.org/10.1098/rspb.1989.0027 
13. SANDELL M, LIBERG 01992 Roamers and stayers: a model on male mating tactics and mating system. Am Nat 139 (1): 177-189. DOI: http:// dx.doi.org/10.1086/285319

14. BIDEAU E, VINCENT JP, QUERÉ JP, ANGIBAULT JM. 1983 Occupation de l' espace chez le chevreuil (Capreolus capreolus L.). I. Cas de mâles. Acta Oecol-Oec Appl 4: 163-184

15. CEDERLUND GN, SAND HKG 1992 Dispersal of subadult moose (Alces alces) in a non migratory population. Can J Zoolog 70 (7): 1309-1314. DOI: http://dx.doi.org/10.1139/z92-183

16. VINCENT JP, BIDEAU E, HEWISON AJM, ANGIBAULT JM 1995 The influence of increasing density on body weight, kid production, home range and winter grouping in roe deer (Capreolus capreolus). J Zool 236 (3): 371-382. DOI: http:/l dx.doi.org/10.1111/j.1469-7998.1995.tb02719.x

17. JEPPESEN JL 1987 Impact of human disturbance on home range, movements and activity of red deer (Cervus elaphus L.) in a Danish environment. Danish Revue of Game Biology 13 (2): 1-38

18. KLEVELAND K 2007 Seasonal home ranges and migration of red deer (Cervus elaphus) in Norway. MSc thesis, University of Oslo, Centre for Evolutionary and Ecological Synthesis, Oslo, Norway, $42 p$

19. JOHNSON CJ, PARKER KL, HEARD DC, GILLINGHAM MP 2002 A multiscale behavioral approach to understanding the movements of woodland caribou. Ecol Appl 12 (6): 18401860. DOI: http://dx.doi.org/10.1890/10510761(2002)012[1840:AMBATU]2.0.CO;2

20. CRAIGHEAD JJ, ATWELL G, O'GARA BW 1972 Elk migrations in and near Yellowstone National Park. Wildlife Monogr 29: 3-48

21. BLANKENHORN HJ, BUCHLI C, VOSER $P$ 1978 Wanderungen und jahreszeitliches Verteilungsmuster der Rothirspopulation (Cervus elaphus L.) im Engalin, Münstertal und Schweizerischen Nationalpark. Rev Suisse Zool 85: 779-789

22. JARNEMO A 2008 Seasonal migration of male red deer (Cervus elaphus) in southern Sweden and consequences for management. Eur J Wildlife Res 54 (2): 327-333. DOI: http://dx.doi.org/10.1007/ s10344-007-0154-7

23. HUDSON RJ, WHITE RG 1985 Bioenergetics of wild herbivores. CRC Press, Boca Raton, FL, USA, $328 \mathrm{p}$
24. LANGVTAN R, ALBON SD 1986 Geographic clines in body weight of Norwegian red deer: a novel explanation of Bergmann's rule? Ecography 9 (4): 285-293. DOI: http://dx.doi. org/10.1111/j.1600-0587.1986.tb01221.x

25. GEORGII B, SCHRÖEDER W 1983 Home range and activity patterns of male red deer (Cervus elaphus L.) in the Alps. Oecologia 58 (2): 238-248. DOI: http://dx.doi.org/10.1007/BF00399224

26. CLUTTON-BROCK TH, GUINNESS F, ALBON SD 1982 Red deer: the Behaviour and Ecology of Two Sexes. Wildlife Behavior and Ecology series. University of Chicago Press, Chicaho, IL, USA, $400 \mathrm{p}$

27. CRAIGHEAD JJ, CRAIGHEAD FC, RUFF RL, O'GARA BW 1973 Home ranges and activity patterns of nonmigratory elk of the Madison drainage herd as determined by radiotelemety. Wildlife Monogr 33: $1-50$

28. GEORGII B 1980 Home range patterns of female red deer (Cervus elaphus L.) in the Alps. Oecologia 47 (2): 278-285. DOI: http://dx.doi.org/10.1007/ BF00346833

29. CEDERLUND G 1981 Daily and seasonal activity pattern of roe deer in a boreal habitat. Viltrevy 11: 315-353

30. FRYXELL JM, GREEVER J, SINCLAIR ARE 1988 Why are migratory ungulates so abundant? Am Nat 131 (6): 781-798. DOI: http://dx.doi. org/10.1086/284822

31. PARKER KL, ROBBINS CT, HANLEY TA 1984 Energy expenditure for locomotion by mule deer and elk. J Wildlife Manage 48 (2): 474-488. DOI: http:/l dx.doi.org/10.2307/3801180

32. CEDERLUND G, LINDSTRÖM E 1983 Effects of severe winters and fox predation on roe deer mortality. Acta Theriol 28 (7): 129-145. DOI: http://dx.doi.org/10.4098/AT.arch.83-9

33. SCHMIDT K 1993 Winter ecology of nonmigratory Alpine red deer. Oecologia 95 (2): 226-233. DOI: http://dx.doi.org/10.1007/BF00323494

34. BRNA J 1981 Prostorni raspored jelenskih krda (mužjaka) u parku prirode "Podunavlje" i neki aspekti njihovog teritorijalnog ponašanja (in Croatian). Zbornik radova Poljoprivrednog fakulteta u Osijeku 7: 147-158

35. HAFNER M 2008 Jelenjad: zgodovina na Slovenskem, ekologija, upravljanje. Zlatorogova knjižnica 34. Lovska zveza Slovenije, Ljubljana, Slovenia, $430 \mathrm{p}$ 
36. SELETKOVIĆ Z 2001 Climate and hydrological conditions in the fir forests of the Dinaric region of Croatia. In: Prpić B (ed) Silver Fir (Abies alba Mill.) in Croatia. Akademija šumarskih znanosti, Hrvatske šume, Zagreb, Croatia, pp 142-146

37. STATSOFT INC 2006 Electronic Statistics Textbook. URL: http://www.statsoft.com/textbook/stathome. html (14 December 2014)

38. THE MINISTRY OF AGRICULTURE, FORESTRY AND WATER MANAGEMENT 2006 Regulation on content, manner of drafting and adoption and approval procedures for hunting management plans, wild game breeding programmes and wild game protection programmes (in Croatian). Official Gazette 40/2006, Zagreb, Croatia. URL: $\quad$ http://narodne-novine.nn.hr/clanci/ sluzbeni/2006 04_40_981.html (12 April 2006)

39. THE MINISTRY OF AGRICULTURE, FORESTRY AND WATER MANAGEMENT 2009 Law on Amendments to the Hunting Law. Official Gazette 75/2009, Zagreb, Croatia. URL: http://narodne-novine. nn.hr/clanci/sluzbeni/2009 06 _75_1792.html (30 June 2009)

40. UGARKOVIĆ D, TIKVIĆ I 2011 Variation of climate in the region of Gorski kotar. Glasnik za šumske pokuse 44: 55-64
41. GROISMAN PY, KARL TR, KNIGHT RW 1994 Observed impact of snow cover on the heat balance and rise of continental spring temperatures. Science 263 (5144): 198-200. DOI: http://dx.doi.org/10.1126/ science. 263.5144 .198

42. CEDERLUND G 1983 Home range dynamics and habitat selection by roe deer in a boreal area in central Sweden. Acta Theriol 28 (30): 443-460

43. HEWISON AJ, VINCENT JP, REBY D 1998 Social organisation of European roe deer. In: Andersen $R$, Duncan P, Linnell JDC (eds) The European Roe Deer. The Biology of Success. Scandinavian University Press, Oslo, Norway, pp 189-219

44. LUCCARINI S, MAURI L, CIUTI S, LAMBERTI P, APOLLONIO M 2006 Red deer (Cervus elaphus) spatial use in the Italian Alps: home range patterns, seasonal migrations, and effects of snow and winter feeding. Ethol Ecol Evol 18 (2): 127145. DOI: http://dx.doi.org/10.1080/08927014.20 06.9522718

45. KOUBEK P, HRABE V 1996 Home range dynamics in the red deer (Cervus elaphus) in a mountain forest in central Europe. Folia Zool 45: 219-222

46. LAMBERTI P, MAURI L, APOLLONIO M 2004 Two distinct patterns of spatial behaviour of female roe deer (Capreolus capreolus) in a mountainous habitat. Ethol Ecol Evol 16 (1): 41-53. DOI: http:// dx.doi.org/10.1080/08927014.2004.9522653

(C) 2015 by the Croatian Forest Research Institute. This is an Open Access paper distributed under the terms of the Creative Commons Attribution License (http://creativecommons.org/licenses/by/4.0). 